4. Nguyễn Cao Luận, Nguyễn Nguyên Khôi, Hồ Lưuu Châu và công sự '(2004), Tình trang lây nhiếm virus viêm gan $C$ và biện pháp đề phòng lây chéo tại khoa Thận nhân tao bệnh viên Bach Mai 2001 2002, Công trình nghiên cứu khoa hoc Bênh viện Bach Mai 2003 - 2004, Nhà xuất bản Y học,

5. Nguyễn Duy Cường và Phạm Đăng Thuân (2014), Tỷ lệ nhiễm virus viêm gan và một số đặc điểm lẩm sàng, cận lâm sàng bệnh viêm gan ở bênh nhân suy thần man có loc máu chu kỳ tai bểnh viện Đại học Y Thái Bình, Ỳ học thực hành, 2 (905), 85-87.

6. Wiam A Alashek, Christopher W McIntyre and Maarten W Taal (2012), Hepatitis B and C infection in haemodialysis patients in Libya: prevalence, incidence and risk factors, BMC infectious diseases, 12 (1), 265.

7. Hoàng Trung Vinh, Phùng Phương Thảo và Pham Thúy Hường (2014), Tỷ lê nhiễm virus viêm gan và một sô đặc điểm lâm sâng, cận lâm sàng bệnh viêm gan ở bệnh nhân suy thận mạn có lọc máu chu kỳ tại bệnh viện Đại học Y Thái Bình, $Y$ hoc thực hành, 2 85்-87.

8. KDIGO 2018 Clinical Practice Guideline for the Prevention, Diagnosis, Evaluation, and Treatment of Hepatitis C in Chronic Kidney DiseaseKidney, International Supplements (2018) 8, 91-165.

\title{
ĐÁNH GIÁ HIÊU QUẢ CHĂM SÓC PHỤC HỒI CHỨC NĂNG SỚM SAU PHẪU THUẬT THOÁT VỊ ĐĨA ĐỆM CộT SỐNG THẮT LƯNG
}

\author{
Nguyễn Thị Thanh Xuân', Nguyễn Anh Phương1, \\ Bùi Vân Dung ${ }^{1}$, Phạm Trung Thành ${ }^{1}$
}

\section{TÓM TẮT}

Mục tiêu: Đánh giá hiệu quả của việc chăm sóc, hướng dẫn phuc hồi chức năng sớm sau mổ thoát vị đĩa đệm cột sống thắt lưng. Đối tượng và phương pháp: Nghiên cứu hồi cứu, mô tả cắt ngang trên 122 bệnh nhân được phẫu thuật thoát vị đĩa đệm cột sống thắt lưng, tai bênh viên108, trong thời gian từ 01/2017 đến 12/2019. Kết quả: Không có sự khác biêt giữa giới tính nam và nữ, tuổi trung bình mắc bệnh là tương đối trẻ $(38,50 \pm 2,40)$ và $(38,43 \pm$ $2,79)$. Cho thấy bênh lý thoát vi đĩa đêm đang có xu hướng trẻ hoá. Hiệu quả điều trị của bệnh nhân trong nhóm điều trị $(96,43 \%)$ cao hơn đáng kể so với nhóm đối chứng (89,29\%). Việc hướng dân tập phục hồi chức năng sớm đem lai hiêu quả giảm đau rõ rểt trên cả ba cách tính là VAS, JOA, ODI (với $p<0.05$ ). Kết luân: Việc chăm sóc, hướng dẫn tập vân động - phuc hồi chức năng sớm đem lại hiệu quả giảm đau rỗ rệt, nâng cao hiêu quả điều trị.

Tư khoá: Chăm sóc sau mổ, phục hồi chức năng, thoát vị đĩa đệm

\section{SUMMARY \\ ASSESSMENT RESULT OF CARE AND EARLY REHABILITATION IN POST-OPERATIVED LOW BACK HERNIATED DISC}

Aim: Assessment results of care and early rehabilitation in post-operatived lumbar herniated disc. Subjects and methods:Employing case-control and cross sectional study, the research focuses on 122 patients that underwent lumbar herniated disc surgery

\section{'Bệnh viện TWQD 108}

Chịu trách nhiệm chính: Nguyễn Thị Thanh Xuân

Email: xuannguyen100483@gmail.com

Ngày nhận bài: 11/9/2021

Ngày phản biện khoa học: 2/10/2021

Ngày duyệt bài: 20/10/2021 at 108 Military Central Hospital from $01 / 2017$ to 12/2019. Results: There are no differences between male and female patients, the average age is relatively young $(38,50 \pm 2,40)$ and $(38,43 \pm 2,79)$. This shows the condition's current tendency to occur in younger people. Treatment's performance in the case group $(96,43 \%)$ is significantly higher than the control group $(89,29 \%)$. Physical therapy resulted in noticible painrelieving effects according to VAS, JOA, ODI $(p<0.05)$. Conclusion: Care and physical therapy help to promptly alleviate pain and increase treatment's performance.

KeywordS: Post-operative care, rehabilitation, herniated disc.

\section{I. ĐẶT VẤN ĐỀ}

Thoái hóa cột sống thắt lưng là bệnh man tính, tiến triển âm thầm tăng dần, là nguyền nhân gây ra nhiều bênh lý côt sống. Thoát vị đĩa đệm cột sống thắt lưng là một biến chứng thường gặp của bênh lý thoái hóa. Tổn thương cơ bản của bênh là tình trang thoái hóa bao xơ dẫn dến nhân nhây đĩa đệm cột sống thoát ra khỏi vị trí bình thường, chèn ép vào ống sống hay các rễ dây thần kinh gây gây nên các cơn đau vùng thắt lưng với các triêu chứng nhức, tê lan doc từ thắt lưng xuống mổng và chân. Hiện nay, thoát vị đĩa đệm cột sống thắt lưng đang có xu hướng tăng cao. Tại khoa cột sống, Bệnh viện 108 đã phẫu thuât rất nhiều trường hợp vị thoát vị đĩa đệm cột sống thắt lưng và mối quan tâm hàng đầu của người bệnh là sớm quay trở lại cuộc sống hàng ngày. Một trong những yếu tố góp phần đến thành công của việc giúp người bệnh sớm quay trở lại cuộc sống hàng ngày chính là công việc chăm sóc, theo dõi, tập vận 
động phụchồi chức năng sớm sau phẫu thuật cho bệnh nhân của đội ngũ điều dưỡng, qua đó nâng cao hiệu quả điều trị, rút ngắn thời gian hồi phục, phòng ngừa tái phát ${ }^{[1,2]}$. Do đó chúng tôi tiến hành nghiên cứu này nhằmđánh giá hiệu quả công tác chăm sócphục hồi chức năng sớm sau phẫu thuật của điều dưỡng cho bệnh nhân phẫu thuật thoát vị đĩa đệm cột sống thắt lưng, góp phần vào nâng cao hiệu quả điều trị.

\section{II. ĐỐI TƯợNG VÀ PHƯƠNG PHÁP NGHIÊN CỨU}

2.1. Đối tượng nghiên cứu. Nghiên cứu được tiến hành trên 112 bệnh nhân được chẩn đoán và phẫu thuật thoát vị đĩa đệm cột sống thắt lưng, từ tháng 01 năm 2017 đến tháng 12 năm 2019 tại Bệnh viện Trung ương Quân đội 108.

\subsection{Tiêu chuẩn lựa chọn bệnh nhân:}

- Bệnh nhân $\geq 18$ tuổi, được chẩn đoán xác định đau cột sống thắt lưng do thoát vị đĩa đệm có chỉ định phẫu thuật lấy thoát vị đĩa đệm.

- Sau phẫu thuật không có biến chứng rò dịch não tủy.

- Bệnh nhân đồng ý tham gia nghiên cứu và tuân thủ điều trị, phối hợp chăm sóc sau mổ.

\subsection{Tiêu chuẩn loại trừ:}

- Bệnh nhân có kèm theo bệnh lý khác vùng cột sống thắt lưng như trượt đốt sống, nhiễm trùng vết mổ cột sống thắt lưng, vẹo cột sống, chân thương cột sống, u vùng cột sống thắt lưng,...

- Bệnh nhẩn có kèm theo bệnh lý toàn thân như bệnh suy gan suy thận,...

- Bệnh nhân không đồng ý tham gia nghiên cứu

\subsection{Phương pháp nghiên cứu}

2.4.1 Thiết kế nghiên cứu. Phương pháp nghiên cứu hồi cứu, mô tả cắt ngang.

Căn cứ theo phương pháp chăm sóc bệnh nhân sau phẫu thuật bệnh nhân được chia làm hai nhóm: nhóm chứng và nhóm nghiên cứu.

- Nhóm đối chứng được chăm sóc thông thường, bao gồm:

Chăm sóc tâm lý người bệnh, chăm sóc giảm đau, chế độ ăn uống-dinh dưỡng, đại-tiểu tiện; chăm sóc giấc ngủ...

- Nhóm nghiên cứu.

Ngoài chăm sóc thông thường như nhóm đối chứng, bệnh nhân được chăm sóc hướng dẫn tập vận động phục hồi chức năng sớm theo quy trình sau:

(1) Ngày thứ nhất sau mổ

- Điều dưỡng hỗ trợ bệnh nhân thay đổi tư thế tại giường 2 giờ/ 1 lần

- Hướng dẫn bệnh nhân tập thở bụng; tư thế nửa nằm, nửa ngồi; nằm ngửa trên giường, tập vận động hai chân; tự tập lăn, lật, nằm nghiêng sang hai bên.

(2). Ngày thứ hai sau mổ

- Hướng dẫn bênh nhân tập ngồi dậy,tập vận động tư thế ngối thõng chân ra mép ngoài giường; tập đứng lên, ngồi xuống với khung tập đi; tập ở tư thế đứng với khung tập đi.

(3). Ngày thứ ba sau mổ

- Hướng dẫn bệnh nhân tập thăng bằng đứng; tập đi với khung tập đi

(4). Ngày thứ tư trở đi

- Tập đi chủ động không cần sự trợ giúp của khung tập đi

- Tập đi theo khả năng của mình, tập nhiều lần trong ngày

\subsubsection{Thang điểm đánh giá}

Để so sánh chất lượng chăm sóc bệnh nhân sau phẫu thuật trong hai nhóm nghiên cứu, sử dụng 3 thang điểm để đánh giá thang điểm JOA, VAS, ODI

- Thang điểm JOA

- Thang điểm đánh giá mức độ đau VAS

- Thang điểm Oswetry

2.4.3. Xử lý số liệu. Các số liệu nghiên cứu được phân tích dựa trên phần mềm thống kê SPŚS 21.0 trong đó sử dụng các thuật toán thống kê như tính tỉ lệ \%, giá trị trung bình, $\mathrm{t}$ test. Với $\mathrm{P}<0.05$ được cho là sự khác biệt có ý nghĩa thống kê.

\section{KẾT QUẢ NGHIÊN CỨU}

3.1. Đặc điểm chung. Tổng số 112 bệnh nhân thoát vị đĩa đệm cột sống thắt lưng đủ tiêu chuẩn được được chia làm hai nhóm nhóm đối chứng và nhóm nghiên cứu, mỗi nhóm có 56 trường hợp. Trong nhóm đối chứng có 30 nam, 26 nữ; với độ tuổi từ 31 đến 46, trung bình $(38,50 \pm 2,40)$ tuổi, thời gian mắc bệnh từ 5 tháng đến 4 năm. Nhóm nghiên cứu có 33 nam và 23 nữ với độ tuổi từ từ 30-47 tuổi, với trung bình $(38,43 \pm 2,79)$ tuổi, thời gian mắc bệnh từ 6 tháng đến 5 năm; kết quả không có sự khác biệt mang ý nghĩa thống kê ( $P>0,05)$. Tuy nhiên, nó cho thấy bệnh lý thoát vị đĩa đệm thắt lưng đang có xu hướng trẻ hoá, đưa ra một khuyến cáo đáng báo động về môi trường cũng như các áp lực công việc lên giới trẻ hiện nay.

3.2. Đánh giá hiệu quả điêu trị giữa hai nhóm nghiên cứu: Hiệu quả điều trị của bệnh nhân trong nhóm điều trị $(96,43 \%)$ cao hơn đáng kể so với nhóm đối chứng $(89,29 \%)$ và sự khác biệt này mang có ý nghĩa thống kê (P $<0,05)$. (Bảng 1). 
Bảng 1. Đánh giá hiệu quả điệu trị của hai nhóm

\begin{tabular}{|c|c|c|c|c|c|c|}
\hline \multirow{2}{*}{ Nhóm } & Số beểnh & \multicolumn{5}{|c|}{ Hiệu quả điều trị } \\
\cline { 3 - 7 } & nhân & Cải thiện rõ & Đỡ & Giảm & Chưa cải thiện & Tỉ lệ (\%) \\
\hline Nhóm đối chứng & 56 & 8 & 24 & 18 & 6 & 89.29 \\
\hline Nhóm nghiên cứu & 56 & 12 & 26 & 16 & 2 & 96.43 \\
\hline
\end{tabular}

3. Đánh giá hiệu quả giảm đau dựa trên thang điếm VAS, JOA và ODI

Bệnh nhân sau phâ̂u thuật và được hướng dẫn tập vận động phục hồi chức năng sớm có điểm VAS, JOA và ODI cải thiện hởn nhiêu so với bệnh nhẩn sau phẫu thuật trong nhóm đối chứng. Đồng thời sự khác nhau đó có ý nghĩa thống kê khi $P<0,05$ (Bảng 2).

Bảng 2. Đánh giá hiếu quả dứa trên thang điếm VAS, JOA và ODI

\begin{tabular}{|c|c|c|c|c|c|c|c|}
\hline \multirow[b]{2}{*}{ Nhóm } & \multirow[b]{2}{*}{$\begin{array}{c}\text { Số } \\
\text { Lượng }\end{array}$} & \multicolumn{2}{|c|}{ Điếm VAS } & \multicolumn{2}{|c|}{ Điếm JOA } & \multicolumn{2}{|c|}{ Điếm ODI } \\
\hline & & $\begin{array}{l}\text { Trước } \\
\text { điều trị }\end{array}$ & $\begin{array}{c}\text { Sau } \\
\text { điêu trị }\end{array}$ & $\begin{array}{c}\text { Trước điều } \\
\text { trị }\end{array}$ & $\begin{array}{c}\text { Sau } \\
\text { điều trị }\end{array}$ & $\begin{array}{c}\text { Trước điều } \\
\text { trị }\end{array}$ & $\begin{array}{c}\text { Sau } \\
\text { điêuu trị }\end{array}$ \\
\hline & & & & $10.19 \pm 1.20$ & & $28.31 \pm 4.18$ & \\
\hline & & & $4.01 \pm 0.16$ & $10.13 \pm 1.01$ & $24.99 \pm 2.10$ & $27.88 \pm 4.36$ & $10.00 \pm 2.1$ \\
\hline
\end{tabular}

\section{BÀN LUÂ̂N}

Thoát vị đĩa đệm cột sống thắt lưng là một trong những nguyển nhân chính gây ra đau vùng côt sống thắt lưng. Cùng với sự phát triển của xã hội hiện đại, áp lực công việc ngày càng lớn, thời gian làm việc ngồi lâu dài, thiếu thời gian tập luyện sức khỏe đặc biệt là việc tăng cường sức mạnh khối cơ cạnh sống. Theo thời gian khối cơ cạnh sống thường dễ hay bị tổn thương, giảm khả năng giữ vững cột sống, đầy nhanh quá trình thoái hóa cột sống, qua đó tăng tỉ lệ người bệnh bị thoát vị đĩa đệm cột sống lưng.

Tuy thoát vị đĩa đệm không gây nguy hiểm trực tiếp đến sinh mạng, nhưng những triệu chứng mà thoát vị đĩa đệm đem đến thường làm bệnh nhân thường rất khó chịu, ảnh hưởng tới chất lượng cuộc sống. Khả nằng vận động của bệnh nhân bị giảm sút rõ rệt, hạn chế vận động cột sống như cúi ngửa, nghiêng xoay do đau. Hiện nay, phẫu thuật lấy thoát vị đĩa đệm là một trong những phương pháp điều trị có hiệu quả đối với bênh nhân thoát vi đĩa đệm. Tuy vầy hiêu quả sau phẫu thuật đối với từng bệnh nhân khác nhau là khác nhau. Cùng với sự can thiệp của phẫu thuật, chăm sóc hướng dẫn bệnh nhân tập vận động sau phẫu thuật có ý nghĩa trong việc rút ngắn thời gian điều trị, cải thiện triệu chứng để bệnh nhân sớm trở lại cuộc sống bình thường ${ }^{[1]}$.

Bệnh nhân thoát vị đĩa đệm thường phải chịu đựng những triệu chứng như đau lưng, đau tê lan xuống chân, hạn chế vận động cột sống trong thời gian dài, ànhhưởng nghiêm trọng đên sức khỏe thể chất và tinh thần của bệnh nhân. Tích cực quan tâm, chăm sóc tâm lý, chăm sóc giảm đau cũng như chăm sóc chế độ ăn ngủ của bệnh nhân sau phẫu thuật góp phần cải thiên các triệu chứng nêu trên ${ }^{[3]}$. Trong nghiên cứu của chúng tôi cho thây tổng tỷ lệ hiệu quả điều trị cho bệnh nhân trong nhóm điều trị $(96,43 \%)$ cao hơn đáng kể so với nhóm chứng $(89,29 \%)$ sự khác biệt này có ý nghĩa thống kê $(P<0,05)$. Cùng với sự chăm sóc về tâm lý, giảm đau, chế độ ăn uống tích cực phối hợp chăm sóc tập vận động phục hồi chức năng khối cơ cốt lõi sớm đã mang lại hiêu quả điều trị tốt hơn so với khi chỉ thực hiện chằm sóc tâm lý, giảm đau thông thường.

Hiệu quả giảm đau trong nhóm nghiên cứu tốt hởn so với nhóm đối chứng, bệnh nhân trong nhóm nghiên cứu có điểm VAS, JOA và ODI cải thiện hơn nhiều so với trong nhóm đối chứng. Các khối cơ cốt lõi là cơ bao quanh cơ thể ở phía trước và phía sau của bụng, các khối cơ cạnh sống, nhưng khối cơ này rất quan trọng đối với sự ổn định của cột sống ${ }^{[4-6]}$. Cùng với sự quan tẩm về chăm sóc tâm lý, giảm đau thông qua sử dụng thuốc thităng cường sức mạnh cho khối cơ này thông qua việc tập vận động sau phẫu thuật sớm như tại bệnh viện chúng tôi giúp cải thiện sức bền của nhóm cớ, giảm khả năng tái tổn thương, góp phần mang lại hiệu quả điều trị tốt nhất cho bệnh nhân.

\section{KẾT LUẬN}

Qua nghiên cứu đánh giá hiệu quả công tác chăm sóc tập vận động phục hồi chức năng sớm sau phẫu thuật cho bệnh nhân thoát vị đĩa đêm cột sống lưng trên 112 bệnh nhân cho thấy tầm quan trọng của việc hướng dẫn tập vận động phuc hồi chức năng sớm cho bệnh nhân sau phẩu thuật. Phối hợp tập vận động và chăm sóc tâm lý, giảm đau góp phần tăng hiệu quả điều trị, rút ngắn thời gian hồi phục, sớm đưa bệnh nhân trở lại hoạt động bình thường hàng ngày.

\section{TÀI LIẸU THAM KHẢO}

1. KERNC D, STROJNIK V, VENGUST R. Early initiation of a strength training based rehabilitation after lumbar spine fusion improves core muscle strength: a randomized controlled trial [J]. Journal 
of Orthopaedic Surgery and Research, 2018, 13(1):

2. HEBERT J J, FRITZ J M, THACKERAY A, et al. Early multimodal rehabilitation following lumbar disc surgery: a randomised clinical trial comparing the effects of two exercise programmes on clinical outcome and lumbar multifidus muscle function [J]. British Journal of Sports Medicine, 2015, 49(2): 100-6.

3. GREENWOOD J, MCGREGOR A, JONES $F$, et al. Rehabilitation Following Lumbar Fusion Surgery [J]. Spine, 2016, 41(1): E28-E36.

4. WEN-DIEN CHANG H-Y L, , PING-TUNG LAI. Core strength training for patients with chronic low back pain [J]. Physical Therapy Science, 2015, 27(619-22

5. CALATAYUD J, GUZMÁN-GONZÁLEZ B, ANDERSEN $\mathbf{L} \mathbf{L}$, et al. Effectiveness of a GroupBased Progressive Strength Training in Primary Care to Improve the Recurrence of Low Back Pain Exacerbations and Function: A Randomised Trial [J]. International Journal of Environmental Research and Public Health, 2020, 17(22):

6. WEN-DIEN CHANG H-Y L, PING-TUNG LAI. Core strength training for patients with chronic low back pain [J]. Physical Therapy Science, 2015, 27(619-22.

\section{ĐÁNH GIÁ KẾT QUẢ CHĂM SÓC NGƯờI BÊNH SAU PHẪU THUÂT CẮT THỰC QUẢN TẠO HİNH NộI SOI VÀ MộTT Số YẾU TỐ LIÊN QUAN TẠI BỆNH VIỆN K NĂM 2020 -2021}

\section{TÓM TẮT}

Mục tiêu: Phân tích kết quả chăm sóc người bệnh phẫu thuật nội soi cắt thực quản tạo hình và một số yếu tố liên quan. Phương pháp nghiên cứu: Nghiên cứu mô tả tiến cứu trên 138người bênh ung thư thực quản được điều trị theo phương pháp phẫu thuật nội soi tạo hình tại Khoa Ngoại bụng 2 - Bệnh viện $\mathrm{K}$ từ tháng 01/2020 đến tháng 5/2021. Kết quả chăm sóc người bệnh sau phẫu thuật được đánh giá qua 3 mức đô tốt, trung bình, không tốt và mức độ ảnh hưởng của một số yếu tố có liên quan đến tình trạng nhiễm khuẩn bênh viện (NKBV). Số liệu được thu thâp, xử lý, làm sạch và nhập vào máy tính bằng phần mềm Epidata và Excel. Xử lý số liệu bằng phần mềm thống kê Stata 14. Kết quả: Đa số người bệnh sau điều trị chăm sóc đat kết quả tốt $(72,5 \%)$, trung bình $(26,8 \%)$. Hâu hết các bệnh nhân đều đã ổn định khi xuất viện. Có 1 trường hơơ tử vong sau phẫu thuâtt. Các yếu tố ảnh hưởng đến nhiễm khuẩn bệnh viện bao gồm số ngày nằm viện, hóa trị trước mổ, tiền sử đái tháo đường, tân suất chăm sóc ống màng phổi với sự khác biệt có ý nghĩa thống kê $p<0,05$. Kết luận: Chặm sóc theo đúng quy trình cho người bệnh sau phẫu thuật nội soi cắt thực quản taohinh có kết quả tích cực và giảm nguy cơ nhiếm khuẩn bênnh viện.

Tư khóa: Ung thư thực quản, phẫu thuật nội soi.

\section{SUMMARY}

EVALUATE RESULTS OF NURSING PATIENTS AFTER LAPAROSCOPIC ESOPHAGECTOMY AND SOME RELATED FACTORS AT K HOSPITAL IN 2020-2021

Objectives: Analysis the results of nursing for patients undergoing laparoscopic esophagectomy and

*Đại học Thăng Long

Chịu trách nhiệm chính: Mai Văn Hạnh

Email: hanacuong@gmail.com

Ngày nhận bài: 5/9/2021

Ngày phản biên khoa hoc: 28/9/2021

Ngày duyệt bài: $21 / 10 / 2021$

\section{Mai Văn Hạnh*, Phạm Quốc Đạt*}

some related factors. Methods: A prospective descriptive study on 138 esophageal cancer patients treated by laparoscopic plastic surgery at Abdominal SurgeryDepartment No2- K Hospital from January 2020 to May 2021. Outcomes of patients care after surgery were assessed through 3 levels of good, medium, and bad and the influence of some factors related to hospital-acquired infection. Data were collected, processed, cleared and computerized by using Epidata and Excel software. Data processing using Stata 14 statistical software. Results: The majority of patients afterlaparoscopic esophagectomy treatment achieved good results $(72.5 \%)$, average $(26.8 \%)$. Most of the patients were stable on discharge. There was 1 case of death after surgery. Factors affecting hospital-acquired infection include hospital nursing days, preoperative chemotherapy, history of diabetes, frequency of pleural tube care with statistical significance $p<0.05$. Conclusion:Take care of patients after endoscopic esophagectomy has good results and reduces the risk of hospital-acquired infections.

Key words: Esophageal cancer,laparoscopic esophagectomy surgery

\section{I. ĐẶT VẤN ĐỀ}

Ung thư thực quản (UTTQ) là bệnh ung thư khá phổ biến ở Việt Nam, là một trong 6 nguyên nhân hàng đầu gầy tử vong. Ở Việt Nam, UTTQ nằm trong 10 loại ung thư hàng đầu, ước tính chiếm khoảng $7 \%$ trong ung thư đường tiêu hóa, trong đó nam giới chiếm tî lệ cao hơn nữ giới. UTTQ thường có tiên lượng xấu, thời gian sống thêm thường $<9$ tháng và tî lệ sống 5 năm thường $<20 \%$. Những bênh nhân này được chỉ định điều trị bằng các phương pháp khác như hóa trị, xạ trị, hóa xạ trị đồng thời, nhằm mục đích điêuu trị bệnh và cải thiện triệu chứng, chủ yếu giúp bệnh nhân có thể ăn uống, nâng cao chất lượng cuộc sống. Phẫu thuật điều trị UTTQ cho đến hiện nay vẫn còn đang coi là một phẫu 